\title{
Experience-Dependent Regulation of Dentate Gyrus Excitability by Adult-Born Granule Cells
}

\author{
Eun Hye Park, ${ }^{1,3}$ Nesha S. Burghardt, ${ }^{2,4}$ Dino Dvorak, ${ }^{3}$ René Hen, ${ }^{2}$ and André A. Fenton ${ }^{1,3}$ \\ ${ }^{1}$ Center for Neural Science, New York University, New York, New York 10003, ${ }^{2}$ Departments of Neuroscience and Psychiatry, Columbia University, New \\ York, New York 10032, ${ }^{3}$ State University of New York, Downstate Medical Center, Brooklyn, New York 11203, and ${ }^{4}$ Department of Psychology, Hunter \\ College, City University of New York, New York, New York 10065
}

Behavioral studies have established a role for adult-born dentate granule cells in discriminating between similar memories. However, it is unclear how these cells mediate memory discrimination. Excitability is enhanced in maturing adult-born neurons, spurring the hypothesis that the activity of these cells "directly" encodes and stores memories. An alternative hypothesis posits that maturing neurons "indirectly" contribute to memory encoding by regulating excitation-inhibition balance. We evaluated these alternatives by using dentate-sensitive active place avoidance tasks to assess experience-dependent changes in dentate field potentials in the presence and absence of neurogenesis. Before training, X-ray ablation of adult neurogenesis-reduced dentate responses to perforant-path stimulation and shifted EPSP-spike coupling leftward. These differences were unchanged after place avoidance training with the shock zone in the initial location, which both groups learned to avoid equally well. In contrast, sham-treated mice decreased dentate responses and shifted EPSP-spike coupling leftward after the shock zone was relocated, whereas X-irradiated mice failed to show these changes in dentate function and were impaired on this test of memory discrimination. During place avoidance, excitation-inhibition coupled neural synchrony in dentate local field potentials was reduced in $\mathrm{X}$-irradiated mice, especially in the $\theta$ band. The difference was most prominent during conflict learning, which is impaired in the $\mathrm{X}$-irradiated mice. These findings indicate that maturing adult-born neurons regulate both functional network plasticity in response to memory discrimination and dentate excitation-inhibition coordination. The most parsimonious interpretation of these results is that adult neurogenesis indirectly regulates hippocampal information processing.

Key words: dentate gyrus; field potential; maturing neuron; neurogenesis; place avoidance task

\section{Significance Statement}

Adult-born neurons in the hippocampal dentate gyrus are important for flexibly using memories, but the mechanism is controversial. Using tests of hippocampus-dependent place avoidance learning and dentate electrophysiology in mice with normal or ablated neurogenesis, we find that maturing adult-born neurons are crucial only when memory must be used flexibly, and that these neurons regulate dentate gyrus synaptic and spiking responses to neocortical input rather than directly storing information, as has been proposed. A day after learning to avoid the initial or changed locations of shock, the dentate synaptic responses are enhanced or suppressed, respectively, unlike mice lacking adult neurogenesis, which did not change. The contribution of adult neurogenesis to memory is indirect, by regulating dentate excitation-inhibition coupling.

\section{Introduction}

Because of the presence of stem cells in the subgranular zone, neurogenesis in the dentate granule cell layer continues through-

\footnotetext{
Received March 6, 2015; revised June 12, 2015; accepted July 15, 2015.

Author contributions: E.H.P., N.S.B., and A.A.F. designed research; E.H.P. and N.S.B. performed research; D.D. contributed unpublished reagents/analytic tools; E.H.P., D.D. and A.A.F. analyzed data; E.H.P., N.S.B., R.H., and A.A.F. wrote the paper.

This work was supported by National Institutes of Health Grant R01AG043688 to A.A.F., and R.H., Grant R01MH084038 to A.A.F., Grant R21NS091830 to A.A.F., Grant R37 MH068542 to R.H., and Grant NYSTEM-C029157 to R.H.

The authors declare no competing financial interests.

Correspondence should be addressed to Dr. André A. Fenton, Center for Neural Science, New York University, 4 Washington Place, Room 980, New York, NY 10003. E-mail: afenton@nyu.edu.
}

out life (Alvarez-Buylla and Lim, 2004), creating distinct pools of maturing and mature granule cells (Fig. 1A). These cells are important for optimal hippocampal function (Kempermann, 2008; Aimone et al., 2011; Sahay et al., 2011b), but their functional role is controversial (Piatti et al., 2013). It is debated whether maturing granule cells encode memories directly (see next paragraph) or instead modulate dentate activity (see two paragraphs down).

"Direct" hypotheses propose that adult-born neurons store memory by encoding current information in their activity (Ai- 
A

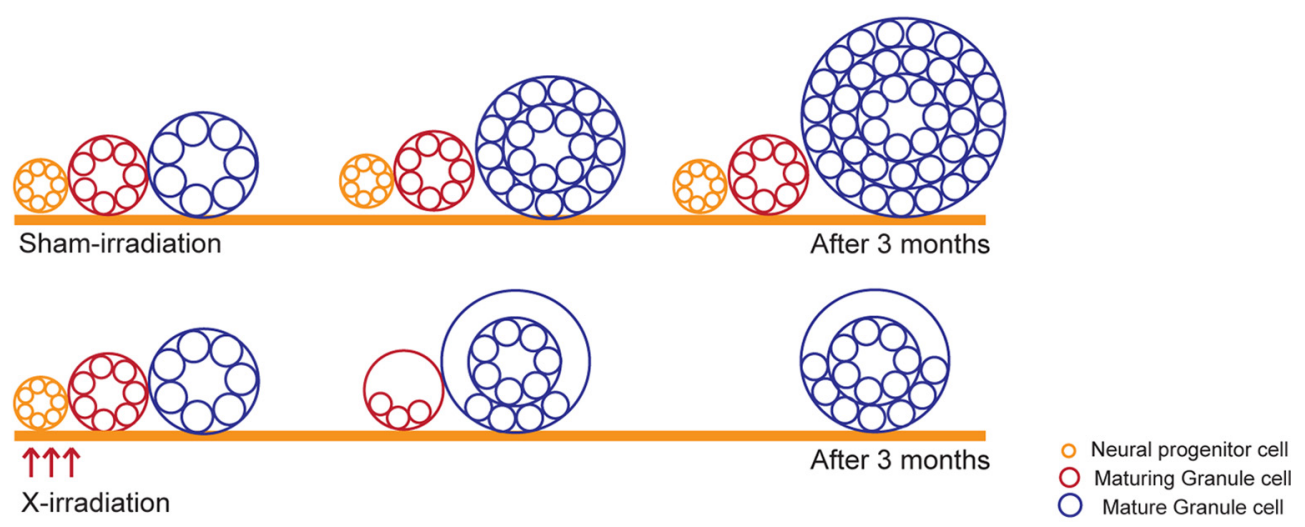

B

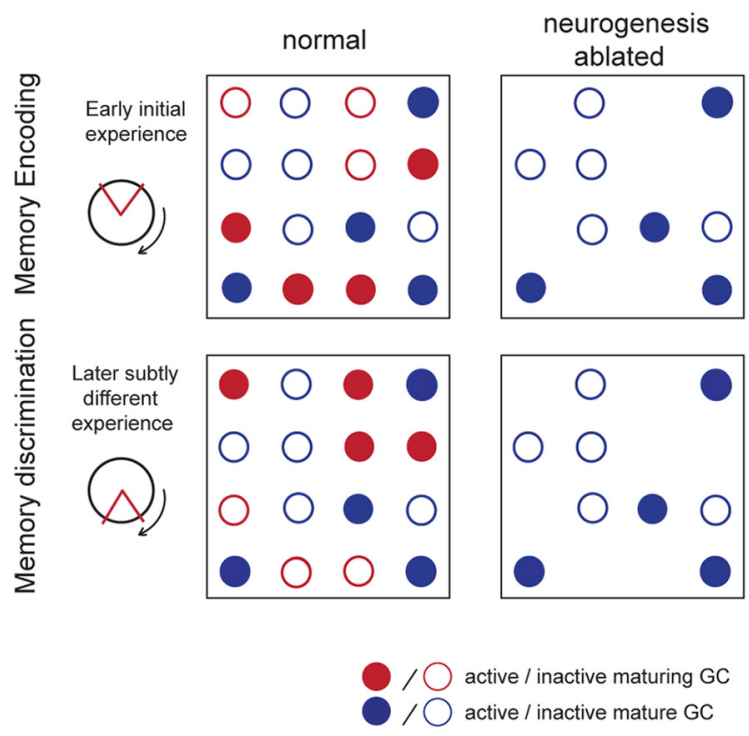

C
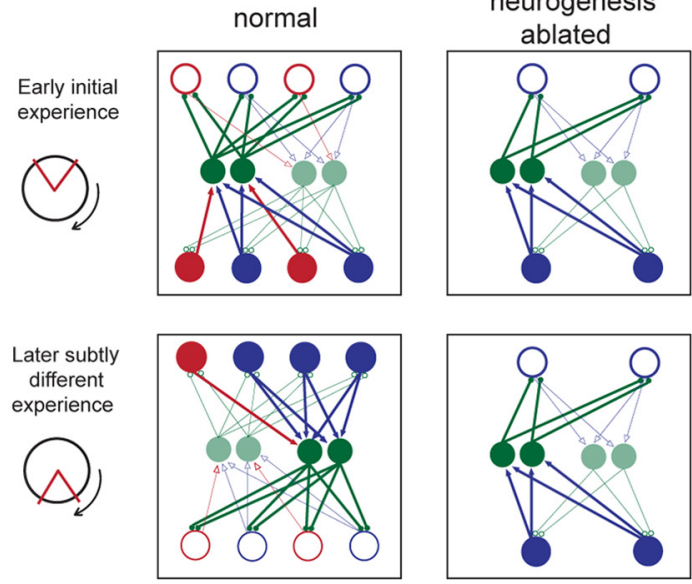

$/ \bigcirc$ active / inactive maturing GC

/ $/$ active / inactive mature GC

/ strongly / weakly active interneuron

\section{D}

Prediction of two different hypotheses

\begin{tabular}{|l|c|c|}
\hline & $\begin{array}{l}\text { Direct } \\
\text { Hypothesis }\end{array}$ & $\begin{array}{l}\text { Indirect } \\
\text { Hypothesis }\end{array}$ \\
\hline $\begin{array}{l}\text { DG } \\
\text { responsiveness }\end{array}$ & Reduced & $\begin{array}{l}\text { Hyperexcitable } \\
\text { imbalanced E-I }\end{array}$ \\
\hline $\begin{array}{l}\text { Memory } \\
\text { Encoding }\end{array}$ & Impaired & Intact \\
\hline $\begin{array}{l}\text { Memory } \\
\text { Discrimination }\end{array}$ & Impaired & Impaired \\
\hline
\end{tabular}

Figure 1. Two classes of hypothesis for the role of maturing dentate granule cells in adult hippocampus. $A$, Schematic describing three populations of cells that are affected by X-irradiation. Irradiation ablates the neural progenitor cell population; and after 3 months, the procedure has effectively eliminated the population of maturing granule cells, the functional role of which we are investigating. The mature granule cell population is also indirectly affected byX-irradiation, in that this population will not growbeyond thematuration of cells that werebormbeforetheX-irradiation. $\boldsymbol{B}$, Directhypotheses positthat theactivity of maturing granulecells directly encodes experienceand associated memories. Thisidea is represented by a matrix depicting theactivity state of a network of mature (blue) and maturing (red) granule cells in adentate gyrus withnormal (left) and ablated (right) levels of neurogenesis. In the normal case, in response to a learning experience (represented as place avoidance with the shock zone centered at $120^{\prime}$ 'lock), a subset of both mature and maturing cells is active (filled). In the ablated case, mature granule cells are available and the active subsethas no difficulty representing the experience. In the normal case, in response to a subtly different experience (represented as conflictplaceavoidance with the shock zone at $60^{\prime}$ clock), a mostly nonoverlapping subset of maturing granule cells is active, whereas mostly the same subset of mature granule cells are active. Thus, it is the activity of the maturing population that is primarily responsible for discriminating the two experiences. In the ablated case, discrimination of two subtly different experiences is poor because the same subset of mature granule cells are active to represent both experiences. Interneurons are not depicted as their role is not emphasized by directhypotheses. C, In contrast, inhibitory interneurons (green) play a central role in indirecthypotheses, which posit that the maturing granule cells indirectly participate in representing experiences and memories by regulating network excitability, via interneurons. This idea is represented by configuring the dentate as a competitivenetworkin which the inhibitony interneurons are preferentially excited by the maturing granule cells (red arrows) relative to the excitation of interneuronsfrom the mature granulecells (blue arrows). In tum, theinterneurons generate feedbackinhibition (green arrows). Cells that are more active generate greater activity (depicted as thicker arrows). In competitive networks, the more active subset of cells silences other cells, even if the inputs to the two subpopulations only differ slightly. Consequently, distinct pattems of granule cell activity discriminate the two place avoidance conditions. Equal numbers of active mature and maturing cells are initially depicted because indirect hypotheses emphasize a differential role of maturing granulesinfeedbackinhibition, ratherthan in encoding perse. Inthecase of normal neurogenesis, overall feedbackinhibition increaseswith time becausematuring granulecells contributeinhibitory connections when they mature, depicted in the "later experience" as a red cell becoming blue. In the case of ablated neurogenesis, overall inhibition is the same during the two experiences, making discriminative patterns of network activity less likely. D, Predictions of the two classes of hypotheses that were tested. E-I, Excitation-inhibition coordination. 
mone et al., 2009, 2010). Such hypotheses are based on observations that 4- to 6-week-old maturing granule cells are more excitable, contribute to LTP only in the presence of inhibition, and functionally integrate with mature granule cells (SchmidtHieber et al., 2004; Ge et al., 2007; Mongiat et al., 2009; Singer et al., 2011). Although direct hypotheses do not include a specific role for inhibitory neurons, a key idea is that adult-born neurons are critical for pattern separation, the neural computation whereby two similar neural input patterns are transformed into distinct outputs to facilitate distinguishing distinct experiences in similar conditions (Marr, 1971). Direct hypotheses explain pattern separation by enhanced excitability of the maturing granule cells, which predisposes activation of the currently maturing subset for each experience (Fig. $1 B$ ).

"Indirect" hypotheses contend that maturing granule cells contribute to pattern separation, memory, and cognitive discriminations by regulating excitability through excitation-inhibition coordination (Fig. 1C) (Kempermann, 2008; Aimone et al., 2011). This is analogous to how interneurons do not encode or transmit information, but their spiking organizes information-carrying principal cell discharge (Schroeder and Lakatos, 2009; Buzsáki, 2010; Kuang et al., 2010; Somogyi et al., 2014; Lasztóczi and Klausberger, 2014). Indirect hypotheses assert that maturing granule cells coordinate the excitation-inhibition coordination within which the memory-encoding activity of mature granule cells is embedded (Aimone et al., 2011; Ming and Song, 2011; Burghardt et al., 2012; Lacefield et al., 2012; Ikrar et al., 2013; Rangel et al., 2013). Indeed, adult-born neurons promote feedforward inhibition as they mature, demonstrating that excitation-inhibition coordination increases with ongoing neurogenesis (Temprana et al., 2015) and that experience can reorganize both excitatory and inhibitory connections with maturing granule cells (Bergami et al., 2015). Indirect hypotheses focus on the local role of maturing adult-born granule cells, rather than their impact on the CA3 target. This is because the focus is on how these maturing cells regulate dentate function as their primary consequence. The effects on CA3 result from overall dentate function, which in the case of direct hypotheses, is primarily due to the maturing cells.

We evaluated these hypotheses using X-ray ablation of neurogenesis, to effectively eliminate the maturing granule cell pool (Fig. 1A). We investigated changes in baseline and experiencedependent dentate responses to neocortical stimulation 3 months after X- or sham-irradiation. We also investigated how ablation alters excitation-inhibition-mediated neural synchrony in dentate local field potentials (LFPs). Direct hypotheses predict that loss of adult-born neurons results in a less responsive dentate and deficits in both memory encoding and discrimination (Fig. 1D). Indirect hypotheses predict that after ablating neurogenesis dentate responses will be hyperexcitable and dysregulated. According to Temprana et al. (2015), this will occur because fewer newborn cells will mature and strongly excite inhibitory neurons (Fig. 1C), but the relationship to inhibition may be more complex. As demonstrated in Hopfield-like network computational models (Rolls et al., 2002; Olypher et al., 2006), such excitationinhibition discoordination selectively disrupts switching between the network representations of experience that is needed for cognitive flexibility and discrimination of memories after subtle environmental changes. Accordingly, indirect hypotheses predict that ablation results in selective loss of the memory discriminations that underlie learning-related behavioral flexibility. These alterations will be most salient during memory discriminations that require suppressing previously acquired conflicting information (Fig. 1D).

\section{Materials and Methods}

Subjects. Adult male $129 \mathrm{~Sv} /$ Ev mice were purchased from Taconic Farms at 8 weeks of age. Procedures used to irradiate animals were conducted at Columbia University and experiments were performed at State University of New York Downstate Medical Center. Throughout the experiment, mice were housed four or five per cage and maintained on a 12/12 $\mathrm{h}$ light/dark cycle. All experiments were conducted in accordance with National Institutes of Health guidelines and approved by Institutional Animal Care and Use Committees of State University of New York Downstate Medical Center and Columbia University. A total of 56 mice were used (Sham: $n=26$; X-ray: $n=30$ ).

$X$-irradiation. To ablate adult neurogenesis, focal X-irradiation of the hippocampus was performed at 10 weeks of age, as previously described (Santarelli et al., 2003). Mice were anesthetized with ketamine (105 mg/ $\mathrm{kg}$, i.p.) and xylazine (7 mg/kg, i.p.) and placed in a stereotaxic frame. The entire body of the animal was covered with a lead shield, except a small area $\left(3.22 \times 11 \mathrm{~mm}^{2}\right)$ above the hippocampus. Animals were exposed to three doses of 5 Gy spaced 2-3 d apart, for a total of 15 Gy. Sham-treated animals were housed, anesthetized, and transported with irradiated mice throughout the experiment but did not receive X-ray treatment. Behavioral training was performed 3-4 months after the last $\mathrm{X}$-ray session to allow for inflammation to subside (Meshi et al., 2006).

Active place avoidance training. Active place avoidance training was conducted as previously described (see Fig. 3A) (Burghardt et al., 2012). Briefly, it involves placing animals on a rotating arena $(40 \mathrm{~cm}$ diameter, 1 $\mathrm{rpm}$ ) and training them to avoid a $60^{\circ}$ shock zone defined by stationary cues within the room. Animals first received a pretraining session, during which time they were put on the rotating arena without shock. Then training began and mice received a brief mild foot shock $(500 \mathrm{~ms}, 60 \mathrm{~Hz}$, $0.2 \mathrm{~mA}$ ) upon entering the shock zone (initial training). A commercial tracking program and overhead camera were used to record the animal's position and to deliver shock accordingly (Tracker, Bio Signal Group). To create a conflict variant of the task (conflict training), the location of the shock zone was moved $180^{\circ}$ from the initial shock position, which is where mice were primarily spending their time during the previous test sessions. Pretraining, initial training, and conflict training each lasted 10 min with an intertrial interval of $50 \mathrm{~min}$. Once training began, animals received 3 trials/d of either initial or conflict training. After each day of behavioral training, mice were returned to their home cage.

In vivo electrophysiology in anesthetized mice. Mice received a single pretraining trial followed by three initial training trials on the first day of behavioral testing (day 1). The next day, these mice were given three additional training trials with the shock zone in its initial location (day 2). On the third day, mice were split into two groups. Half of the animals were given three conflict training trials and the other half were given three more initial training trials (day 3 ). The next day (day 4), animals were anesthetized with urethane $(1.4 \mathrm{~g} / \mathrm{kg}$, i.p) and placed in a stereotaxic frame. After making two small holes in the skull for inserting electrodes, a $125 \mu \mathrm{m}$, epoxy-coated tungsten recording electrode with 1-6 M Ohm impedance (A-M Systems) was lowered into the dentate gyrus (anteroposterior: 2.0 ; mediolateral: 1.4 ; dorsoventral: $1.8-2.0$ relative to bregma) and a bipolar stimulating electrode was placed within the perforant path (anteroposterior: 0.5 anterior to $\lambda$; mediolateral: 3.0 ; dorsoventral: $1.2-1.5$. relative to bregma) on the ipsilateral side (see Fig. $3 B$ ). The stimulating electrode was made by twisting a pair of $75 \mu \mathrm{m}$ Nichrome wires (California Fine Wire). One screw was placed in the posterior skull for the ground. Synaptic responses were stimulated with $100 \mu$ s square pulses applied every $15 \mathrm{~s}$. Evoked potentials were amplified 1000 times, bandpass filtered $1-10 \mathrm{kHz}$ using an $\mathrm{AC}$ amplifier (A-M Systems), and digitized at $32 \mathrm{kHz}$. The field EPSP (fEPSP) slope and population spike (PS) amplitude were analyzed off-line using custommade MATLAB software. Stimulus-response relationships were evaluated with stimulus intensities ranging from 100 to $1000 \mu \mathrm{A}$. At each stimulus intensity, 10 responses were recorded and averaged. To quantify EPSP-spike (E-S) coupling, we calculated the area under curve of the E-S plot. For each subject, the normalized E-S plot was computed by dividing 
A
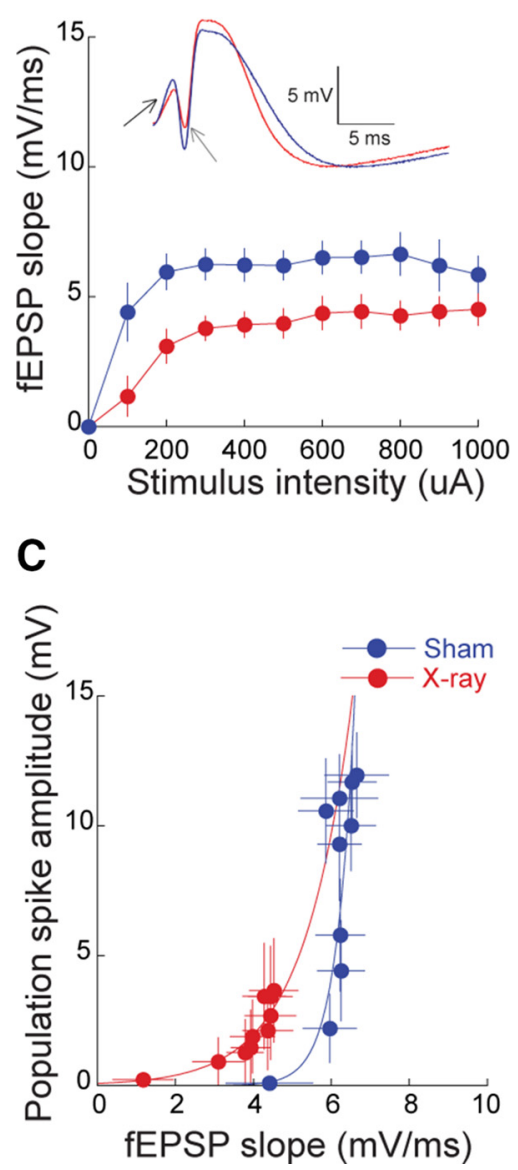

B

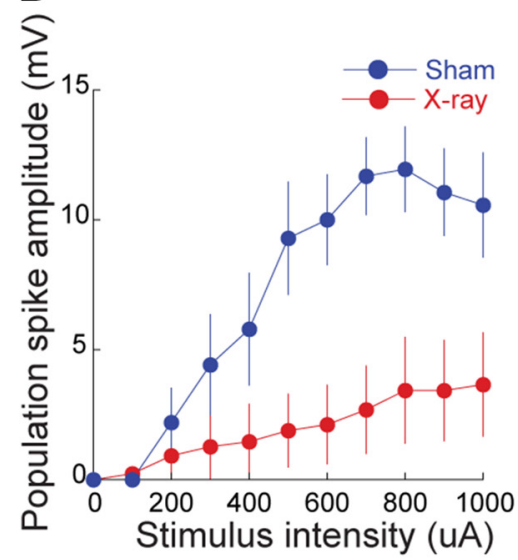

D

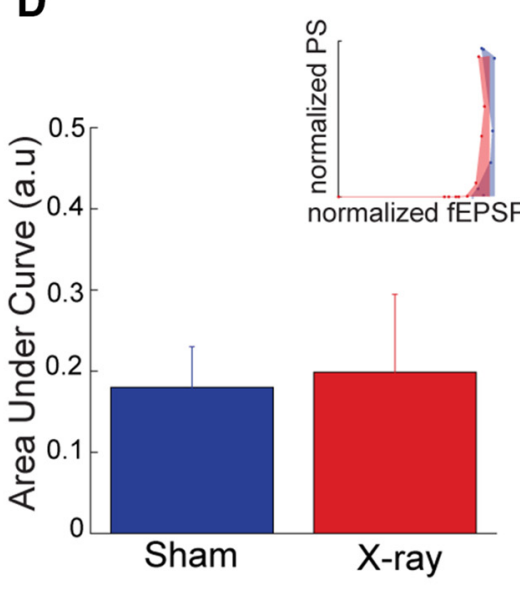

Figure 2. Reduced responses to neocortical stimulation after ablation of neurogenesis by X-irradiation. Input- output relationship measured by $(\boldsymbol{A})$ the slope of the fEPSP response and $(\boldsymbol{B})$ the amplitude of the population spike (Sham: $n=5, X$-ray: $n=5$ ). Inset, Representative responses to $1 \mathrm{~mA}$ stimulations illustrate a shallower slope (black arrow) and lower amplitude (gray arrow) population response in the $X$-irradiated mouse. $\boldsymbol{C}, \mathrm{E}-\mathrm{S}$ coupling and its quantification $(\boldsymbol{D})$ by the average area under the normalized $\mathrm{E}-\mathrm{S}$ curves. Inset, Single representative example.

each measurement by the corresponding maximum field EPSP (fEPSP) and population spike (PS) values. The normalized PS and normalized fEPSP values were plotted to derive the normalized E-S plot for each subject. This was quantified by computing the area under the curve between the normalized fEPSP extremes.

In vivo electrophysiology in freely moving mice. For LFP recordings, electrodes were surgically implanted in the hippocampus (anteroposter: 2.0; mediolateral: 1.4; dorsoventral: $1.8-2.0$ ) and a reference electrode was inserted in the cerebellum. The electrodes were made with $75 \mu \mathrm{m}$ nichrome wires (CFW) that were attached to a Mill-Max connector. After a 1 week recovery period, animals were brought to the experimental room and given a $10 \mathrm{~min}$ pretraining session on the rotating arena without shock followed by three initial training trials with shock (day 1 ). The next day, all mice received three additional initial training trials (day 2). Then for conflict training, the location of the shock zone was switched by $180^{\circ}$, and all mice received three conflict training trials for $2 \mathrm{~d}$ (days 3 and 4). One week after the last training session, animals explored the stationary arena for $10 \mathrm{~min}$. LFP signals were collected each time animals were placed on the arena using a commercial electrophysiology system (dacqUSB, Axona).

LFPs were filtered between 0.1 and $500 \mathrm{~Hz}$ and sampled at $2 \mathrm{kHz}$. As an initial step of the analysis, an artifact rejection algorithm was applied to the data to select continuous segments of artifact-free signals. Such segments that were $\geq 4 \mathrm{~s}$ were used for analysis. The majority of artifacts were related to the foot shock. Specifically, signals saturated and slowly changing DC signals were observed as the recording system recovered from the shock artifact. The algorithm was tuned to identify these two types of artifacts. Periods of very low signal changes defined the DC signal artifacts. Nonchanging signals close to the maximal voltage of the analog-to-digital converter defined saturations. Brief saturations $<2.5 \mathrm{~ms}$ were allowed. Each artifact segment was extended by $1 \mathrm{~s}$ on both sides, and all artifact-free segments $<4$ s long were also discarded. The speed of the animal was computed in 500-ms-long windows using only location values at the beginning and the end of a given window. Running was defined as above $3 \mathrm{~cm} / \mathrm{s}$. Spectral analysis of LFPs was performed using wavelets because of its ability to extract instantaneous estimates of power. First, the LFP signal from the electrode with the highest power in the $\theta(5-12 \mathrm{~Hz})$ range was selected and $z$-score normalized to remove any amplitude differences caused by electrode impedance variations. Second, the signal was convolved with a group of complex Morlet wavelets in the logarithmic range between 2 and $150 \mathrm{~Hz}$. Third, each time series was squared to obtain instantaneous power values for a given frequency. Fourth, only artifact-free segments when the animal was running (speed $>3 \mathrm{~cm} / \mathrm{s}$ ) were selected and averaged into the resulting spectral estimate. Intersubject power values were computed separately for $\theta$ and $\gamma$ bands. For the $\theta$ band, because of the dominant peak, power value was detected separately for each animal as a local peak between 6 and 10 $\mathrm{Hz}$. For the $\gamma$ band, because of the absence of a dominant peak, power values were averaged in $30-50 \mathrm{~Hz}$ and $70-100 \mathrm{~Hz}$ frequency ranges, to exclude the potential contribution of line noise.

Immunohistochemistry and histology. Immediately following electrophysiological recordings, mice were deeply anesthetized with Nembutal (100 mg/kg, i.p.) and perfused through the heart with cold saline followed by cold $4 \%$ paraformaldehyde (PFA) in PBS. The brains were removed, postfixed overnight in $4 \%$ PFA, and then cryoprotected in $30 \%$ sucrose for a minimum of $3 \mathrm{~d}$. Serial $35 \mu \mathrm{m}$ free-floating coronal sections were collected and stored in $0.1 \% \mathrm{NaN}_{3}$ in $\mathrm{PBS}$ at $4^{\circ} \mathrm{C}$. To verify ablation of neurogenesis, immunohistochemistry was used to stain for doublecortin, a marker for immature neurons (data not shown) and to verify the location of the implanted electrodes, some sections were stained with cresyl violet and examined with a light microscope.

Statistics. Statistical comparisons were made using Student's $t$ tests and two-way ANOVA with repeated measures, as appropriate, followed by Fisher's LSD post hoc test. These tests were implemented using Prism, version $6.0 \mathrm{c}$ (GraphPad Software). Error bars in all figures represent SEM.

\section{Results}

\section{Basal network responses of naive animals}

We first investigated whether eliminating neurogenesis changes in vivo electrophysiological properties of the dentate gyrus (Fig. 2). We examined the granule cell response to neocortical input in $\mathrm{X}$-irradiated and sham-treated mice by varying the intensity of perforant path stimulation and measuring the synaptic response as the slope of the fEPSP under urethane anesthesia (Fig. 2A). Ablating neurogenesis reduced the synaptic response to perforant path stimulation. The effects of X-ray treatment $\left(F_{(1,8)}=\right.$ 
7.6, $p=0.02)$ and stimulus intensity $\left(F_{(9,72)}=9.3, p<0.0001\right)$ were significant. The population spike amplitude was also reduced in $\mathrm{X}$-irradiated mice (Fig. $2 B)$. The effects of treatment $\left(F_{(1,8)}\right.$ $=10.1, p=0.01)$, stimulus intensity $\left(F_{(9,72)}=11.8, p<0.0001\right)$, and interaction $\left(F_{(9,72)}=4.3, p=0.0002\right)$ were significant. These observations confirm prior findings that $\mathrm{X}$-irradiation reduces the sensitivity of granule cells to neocortical inputs (Lacefield et al., 2012). Comparing E-S coupling revealed that X-ray treatment shifted the E-S curve leftward (Fig. 2C), suggesting E-S potentiation, an indicator of increased network excitability. However, quantifying E-S coupling values by the area under the curve of the E-S plot normalized to the maximum fEPSP and PS, did not confirm a significant difference between the two groups (Fig. $2 D ; t_{(8)}=0.17, p=0.9$ ). These results indicate that in naive mice, which have no place avoidance training experience, loss of neurogenesis results in reduced responsiveness of the dentate network to neocortical input.

\section{Dentate network properties after place avoidance training}

Next, we examined whether place avoidance training alters these electrophysio-

logical properties. Prior work showed behavioral differences between mice with ablated and normal levels of neurogenesis only when the demand was increased to perform cognitive discriminations (Luu et al., 2012; Tronel et al., 2012; Winocur et al., 2012). In the active place avoidance paradigm, this was demonstrated as an impairment in $\mathrm{X}$-irradiated animals relative to sham controls only when the shock zone location was shifted during conflict training (Burghardt et al., 2012). Here we repeated the active place avoidance training and examined whether dentate responses were altered by training and/or X-irradiation (Fig. 3B). As expected, the two groups were similar in avoiding the initial shock zone, but X-irradiated mice are worse at avoiding the conflict shock zone (effect of group: $F_{(1,32)}=4.2 ; p=0.04$; effect of shock zone location: $\left.F_{(1,32)}=20.1 ; p<0.0001\right)$. Post hoc tests confirmed that avoidance of the initial shock zone was indistinguishable $(p>0.05)$, but avoidance of the conflict shock zone differed between the groups $(p<0.05)$ (Fig. $4 B, C$ ).

One day after the end of place avoidance training to the initial shock zone location (day 4), fEPSP and PS responses were decreased in X-irradiated mice (Fig. 4D) and E-S coupling shifted leftward (Fig. $4 F$, left), replicating the observation in naive mice (Fig. $2 C$ ). The effects of stimulus intensity (fEPSP: $F_{(9,72)}=8.4$; $p<0.0001$; PS: $\left.F_{(9,72)}=14.6 ; p<0.001\right)$ and the interaction between treatment and stimulus intensity were significant on both the fEPSP and the PS (fEPSP: $F_{(9,72)}=2.5 ; p=0.01$; PS: $\left.F_{(9,72)}=3.23 ; p<0.002\right)$.

Two additional groups of $\mathrm{X}$ - and sham-irradiated mice received $2 \mathrm{~d}$ of initial shock zone training followed by $1 \mathrm{~d}$ of conflict training. In contrast to the mice that were trained only to the initial shock zone, the responses of the dentate network were no longer different between X- and sham-irradiated mice $1 \mathrm{~d}$ after

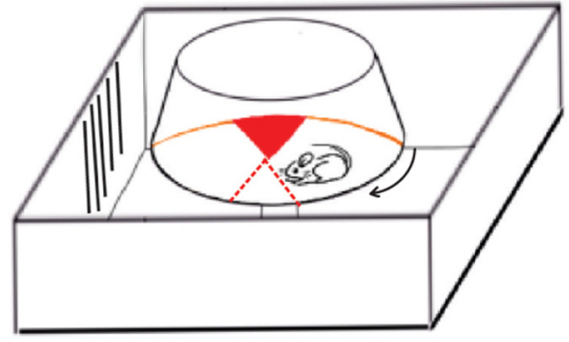

Day2 Day3 Day4
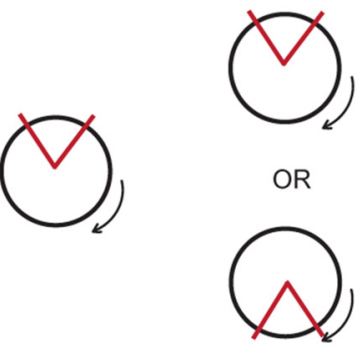

Evoked potential recording under urethane anesthesia

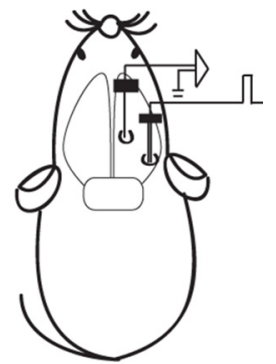

Figure 3. Design of the training-induced cognitive discrimination and acute physiology experiments. Schematics of $(\boldsymbol{A})$ the place avoidance setup and $(\boldsymbol{B})$ the experimental protocol. Red/black sector, Active/inactive shock zone.

the end of conflict training to the new shock zone location (day 4 ) (Fig. 4E). The response to stimulation was similar in the $\mathrm{X}$-irradiated and sham-irradiated mice (Fig. 4E, left), and only the effect of stimulus intensity was significant on both the fEPSP and the PS (fEPSP: $F_{(9,126)}=5.26 ; p<0.0001$; PS: $F_{(9,126)}=8.27$; $p<0.001)$. This change occurred because the fEPSP response decreased in the sham-treated mice after conflict training, as we describe below (Fig. 5). Conflict training also changed E-S coupling, such that the E-S curve from X-irradiated mice was rightshifted compared with sham-irradiated mice (Fig. $4 F$, right). This was confirmed as a significant interaction between the treatment group and the training condition on the area under the E-S curve $\left(F_{(1,22)}=5.33 ; p=0.03\right.$; Fig. $\left.4 G\right)$. This change also occurred because conflict training seemed to change the sham- but not the X-irradiated group's response. These data indicate that memory discrimination can persistently change the functional properties of the dentate network in sham-treated mice. In contrast, changes consequent to memory discrimination are blunted in $\mathrm{X}$-irradiated mice, which is consistent with their cognitive inflexibility (Fig. $4 B, C$ ).

We then investigated how memory discrimination changed dentate network function in each group of mice. To investigate the changes in control mice, we compared the responses of the naive sham animals with those that received training only to the initial shock zone location and the sham animals that were required to discriminate the memories of the two shock zone locations. The responses in naive mice differed from that of mice with training to the initial shock zone location, and conflict training changed the response back toward the naive state (Fig. 5A). There was a significant interaction between training condition and stimulus intensity measured by two-way ANOVA, comparing 
A Initial Training

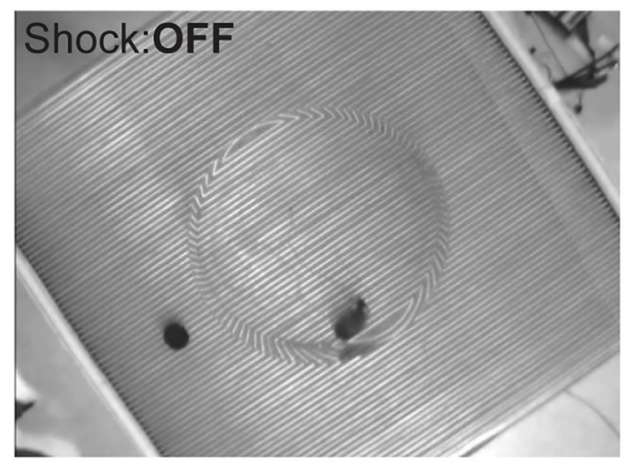

B

Initial Training
Conflict Training

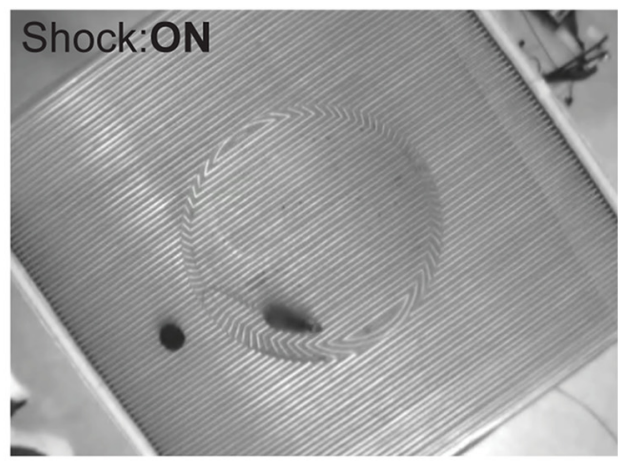

C

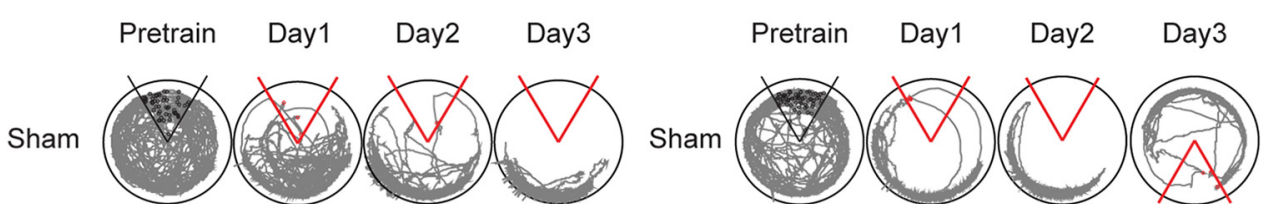

X-ray

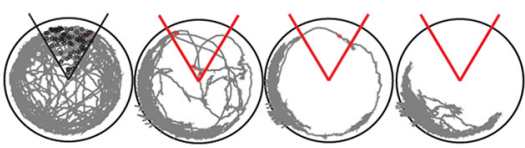

Initial Training

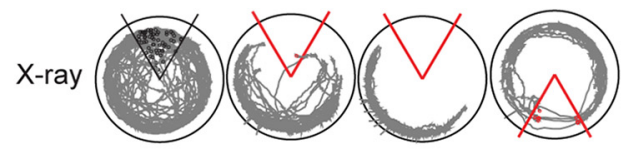

$\mathbf{E}$

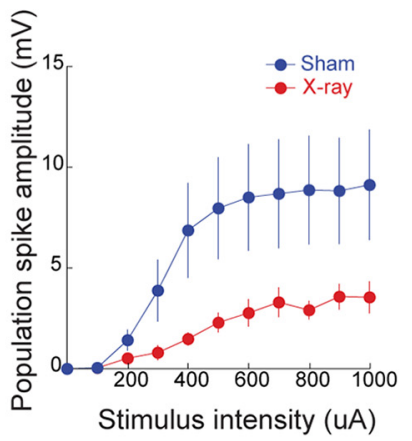

\section{F}

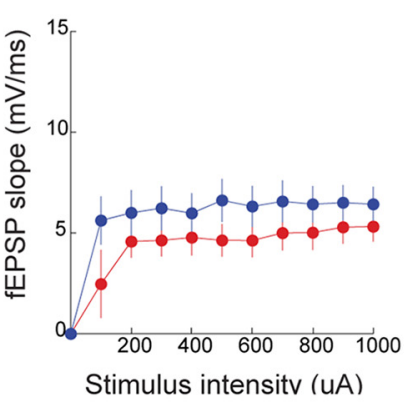

Initial Training

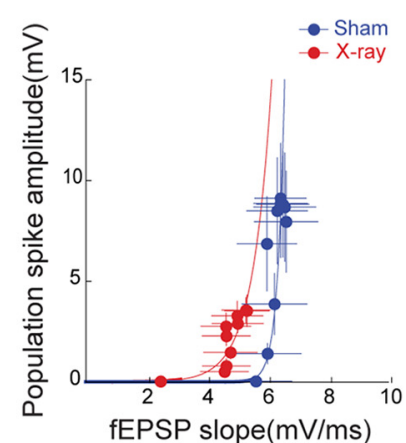

\section{Conflict Training}

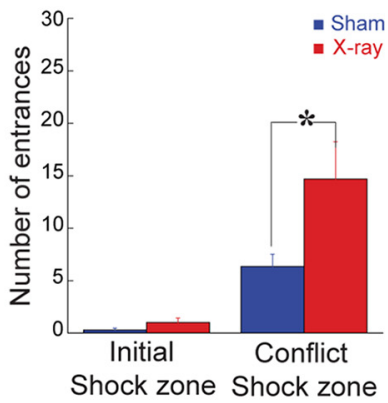

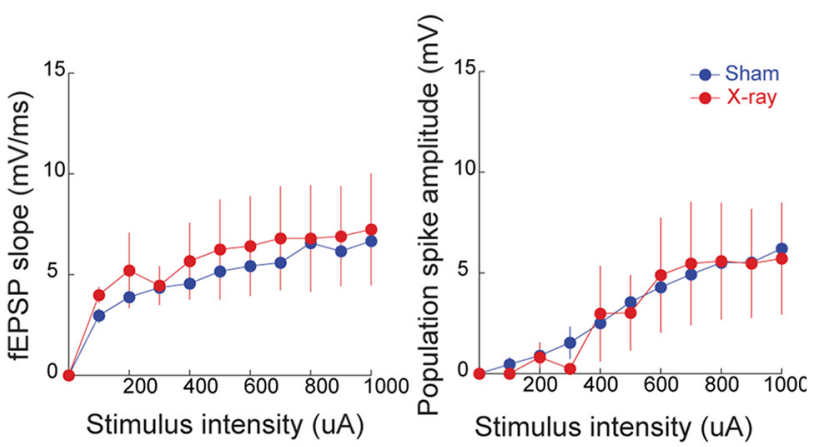

G

Conflict Training

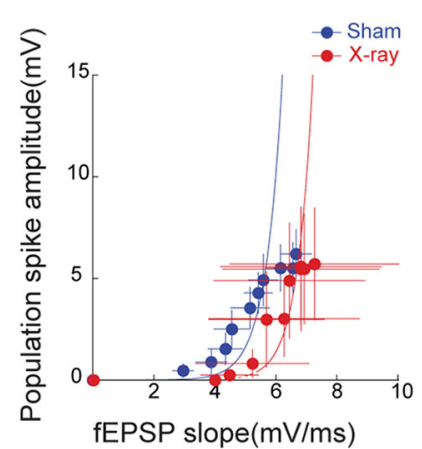

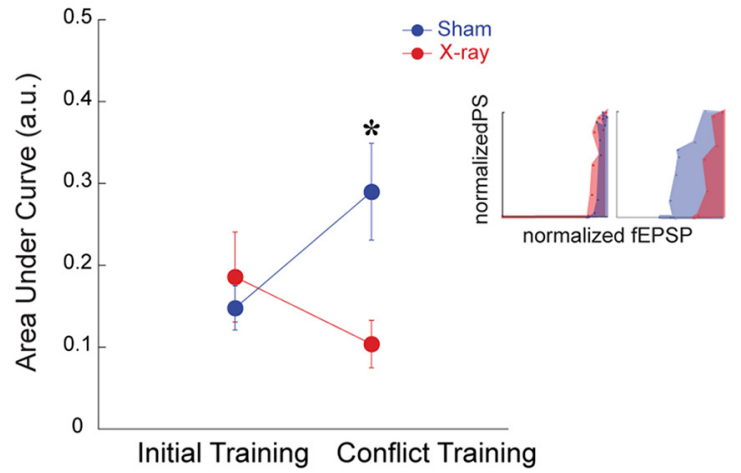

Figure 4. Placeavoidancetraining changes responsestoneocortical stimulation in sham-butnotX-irradiated mice. $\boldsymbol{A}$,Screen shotsfrom videos during thedifferentplaceavoidancetasks with distinctshockzonelocations. These screen shots illustrate that the physical environment i identical across the tasks and only differs in where the mouse is located when experiencing a transient, unsignaled $500 \mathrm{~ms}$ shock. During initial training (left), the mouse is outsidethe shockzone (Shock:OFF), but the samelocation of themouseleads to shock (Shock:ON) during conflicttraining (right). $\boldsymbol{B}$, Tracked behaviorduring place avoidancetraining from a pair ofrepresentative mice across the training days. The tracks show the last trial of each day. C, Summary of place avoidance behavior (Initial training:Sham; $n=7, X$-ray; $n=9$; Conflict training:Sham: $n=10, X$-ray: $n=10$ ). Effect of initial (D) and conflictraining $(\boldsymbol{E})$ on the input- output relationships and E-Scoupling $(\boldsymbol{F})$ (Initial training:Sham; $n=5, \mathrm{X}$-ray; $n=5 ;$ Conflicttraining:Sham: $n=8, \mathrm{X}$-ray: $n=8$ ). The differences seen after training to theinitial shockzone location are changed after conflict training. G, Quantification of E-S coupling shows differences between the groups only after conflict training. * indicates significant difference between the groups. 
A
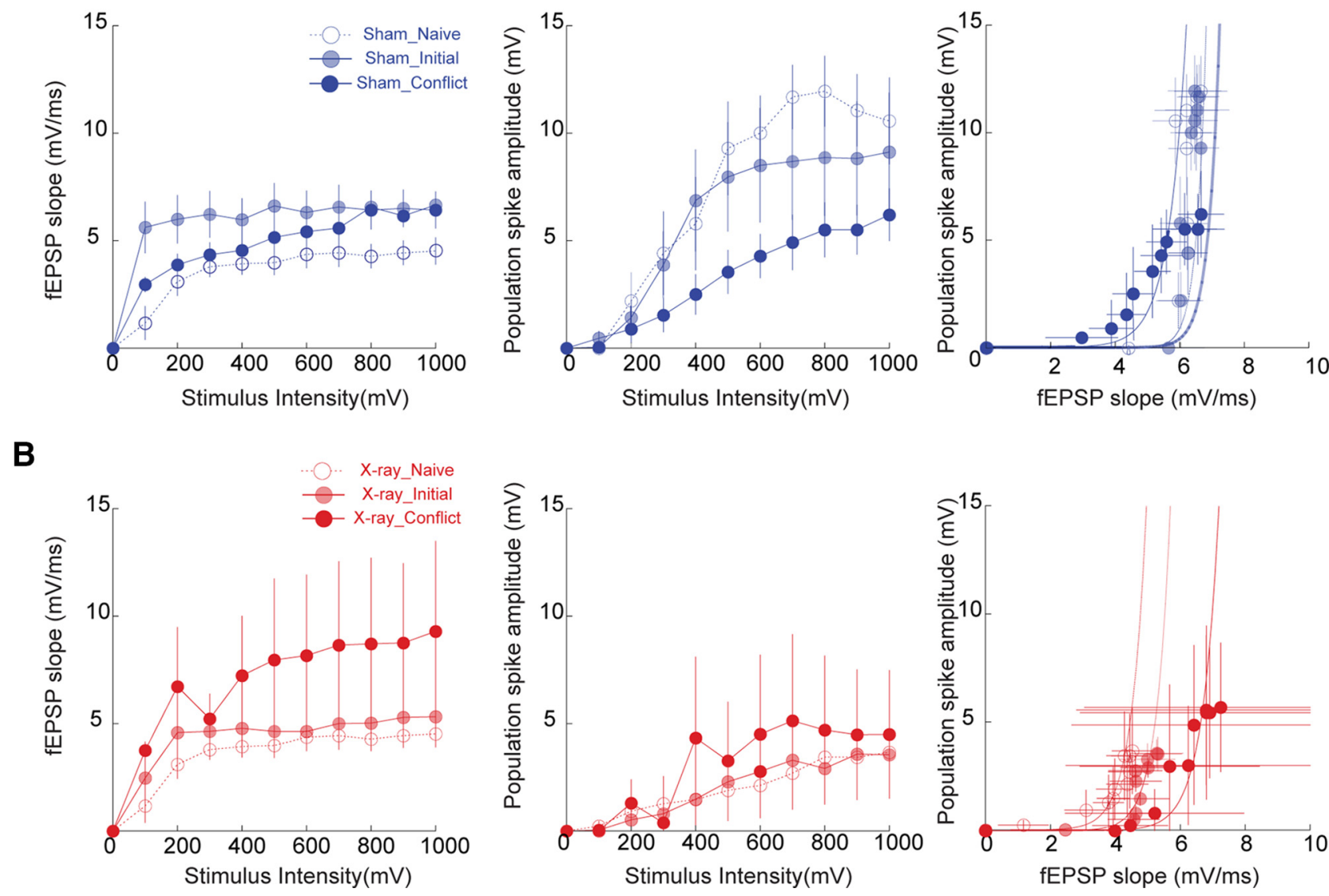

Figure 5. Experience-driven changes in perforant path synaptic responses. The data in Figure 4C-F are replotted to illustrate that place avoidance training changes the input- output fEPSP and population spike relationships, as well as their E-S coupling in $(\boldsymbol{A})$ sham-irradiated and $(\boldsymbol{B}) \mathrm{X}$-irradiated mice. Although experience causes changes in both groups of mice, the specific changes are different and depend on both the status of neurogenesis and the specific behavioral experience.

the input-output curves from the naive, initial, and conflict shock zone conditions (fEPSP: $F_{(18,135)}=3.48$; $p<0.0001$; PS: $\left.F_{(18,135)}=1.82 ; p=0.02\right)$ as well as a significant effect of stimulus intensity (fEPSP: $F_{(9,135)}=12.29 ; p<0.0001$; PS: $F_{(9,135)}=30.69$; $p<0.0001$; Fig. $5 A$ ). In contrast, only the effect of stimulus intensity was significant when the analogous comparison was performed among the $\mathrm{X}$-irradiated mice from the three training conditions (fEPSP: $F_{(9,135)}=4.11 ; p=0.0001$, PS: $F_{(9,135)}=5.24$, $p<0.0001$; Fig. $5 B$ ). Thus, the experience-dependent differences between the X-irradiated and sham-treated mice were largely driven by the experience-dependent changes in the sham-treated mice, whereas the $\mathrm{X}$-irradiated mice expressed relatively small, undetected changes after the different training experiences.

\section{Hippocampal LFPs during and after place avoidance training} Finally, we investigated whether these abnormalities due to loss of adult neurogenesis resulted in altered synaptic activity within the dentate network during awake behaviors. We recorded the hippocampal LFP from the area of maximal $\theta$ oscillation amplitude, in the vicinity of the hippocampal fissure and molecular layer of the suprapyramidal blade of the dentate granule cell layer (Fig. 6). X-irradiated and sham-irradiated mice moved at similar speeds during the experiment (Fig. $6 A ; F$ values $<1.0 ; p$ values $>$ 0.3 ). The groups looked similar in avoiding the initial location of shock, but when the shock zone was changed during conflict training, the $\mathrm{X}$-irradiated mice were impaired compared with the sham mice (Fig. $6 B$; effect of group; $F_{(1,16)}=5.24 ; p=0.036$; effect of shock zone location: $\left.F_{(1,16)}=26.1 ; p<0.0001\right)$. Post hoc tests confirmed that avoidance of the initial shock zone was indistinguishable between the groups $(p>0.05)$, but the groups were different during conflict training $(p<0.05)$. The spectrogram from a pair of representative mice during pretraining and a week after the last training session, both in the absence of shock, suggests there is a mild, wideband reduction in oscillatory power in the X-irradiated mice (Fig. $6 C, D$ ). This trend appeared most prominent in the $\theta$ band, where there was a significant effect of treatment group $\left(F_{(1,48)}=12.61 ; p=0.0009\right)$. Post hoc tests showed group differences in the power spectra during recordings on day 3 conflict training $(p<0.05)$ (Fig. $6 E$, left). Despite a similar trend, the $\gamma$ band differences did not reach significance $(F$ values $<2.3$; p values $>0.05$; Fig. $6 E$, right).

\section{Discussion}

\section{Summary}

The main findings are that memory discrimination is impaired in mice with ablated adult neurogenesis (Fig. $4 B, C$ ), and this learning changes dentate electrophysiology in the presence, but not the absence, of adult-born neurons (Fig. 4D-G). We observed learning-related changes in synaptic network responses $24 \mathrm{~h}$ after training, although experience-dependent hippocampal changes have only been reported to last less than a few hours (Moser et al., 1993, 1994; Moser, 1996; Whitlock et al., 2006; Madroñal et al., 2010). Indeed, we are investigating training-induced synaptic changes independent of adult neurogenesis (Pavlowsky et al., 
A B

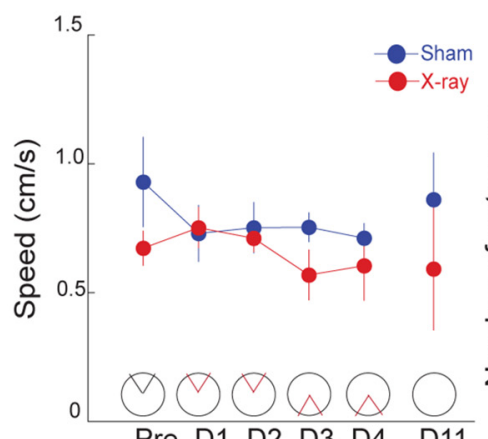

Pre D1 D2 D3 D4 D11

D

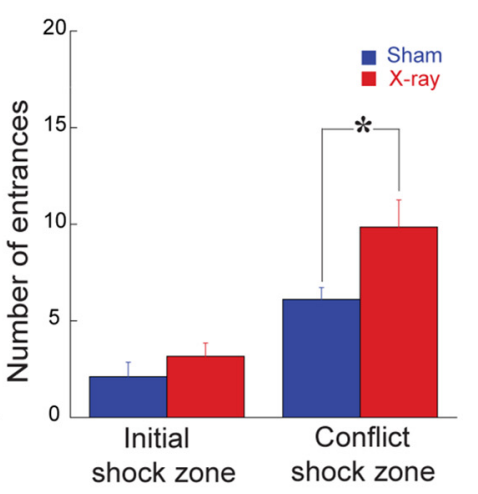

C

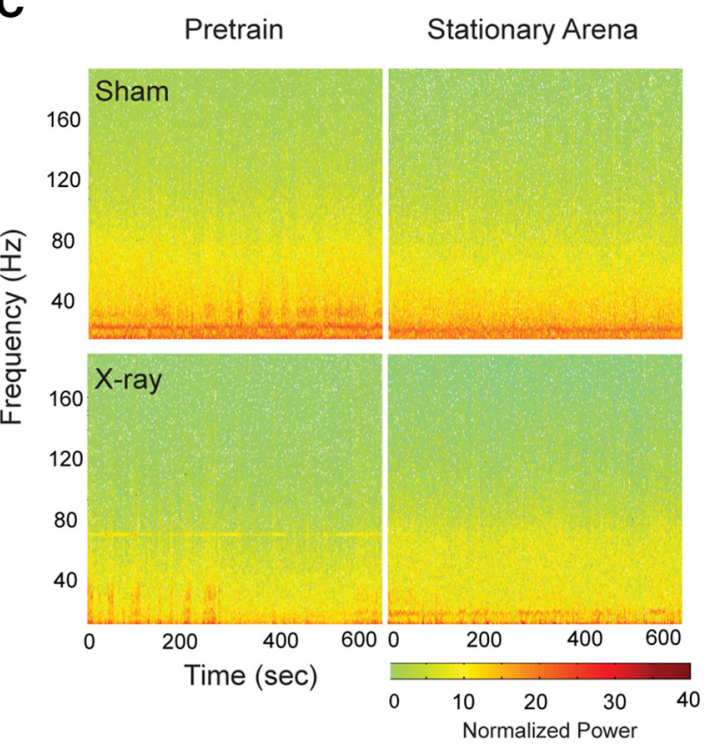

Pretrain

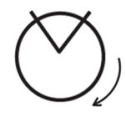

Initial Shock Zone

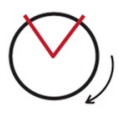

Conflict Shock Zone

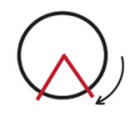

Stationary Arena

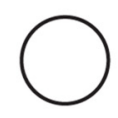

Pretrain

Day1

Day2

Day3

Day4

Day11
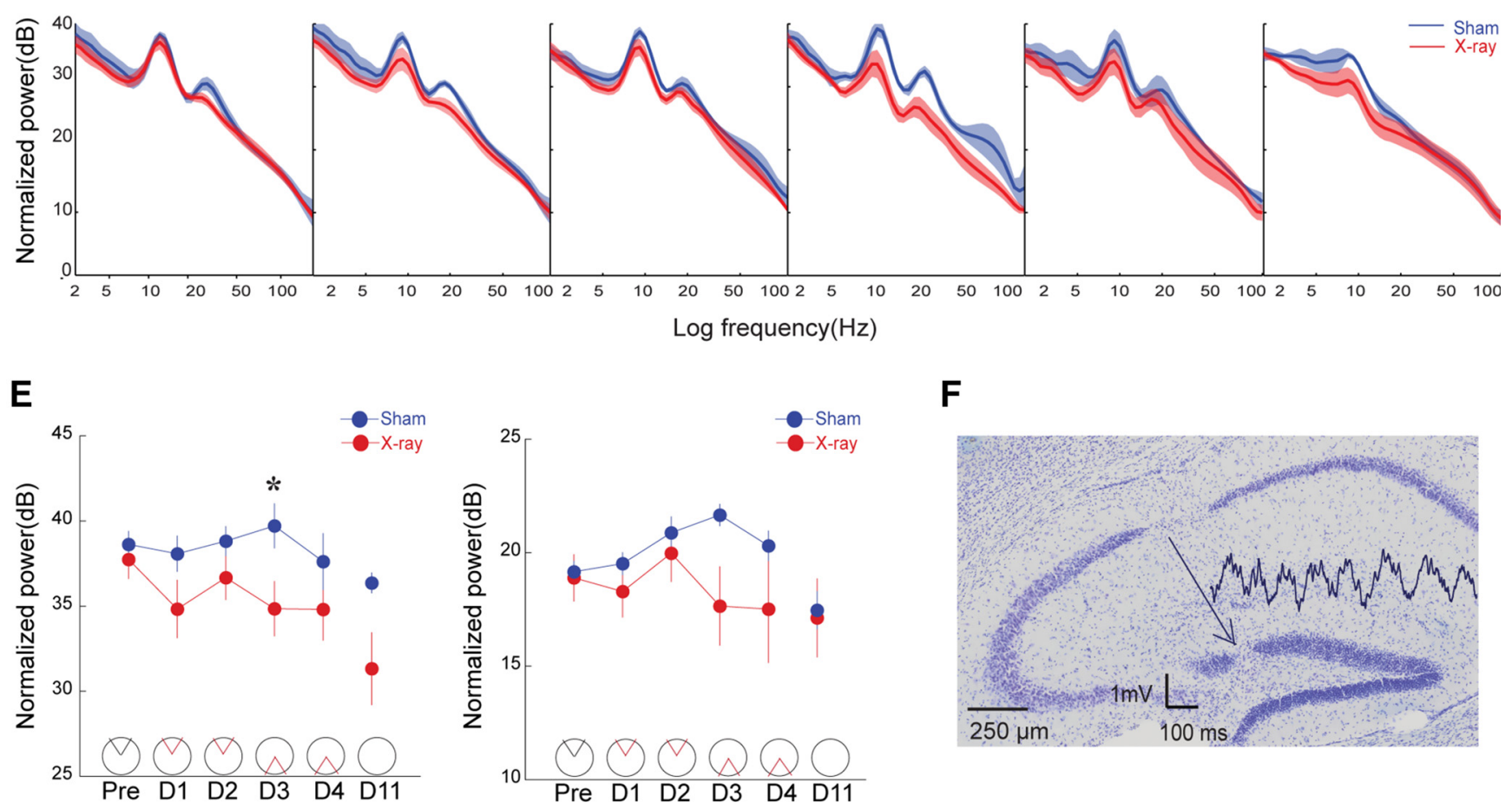

$\mathbf{F}$

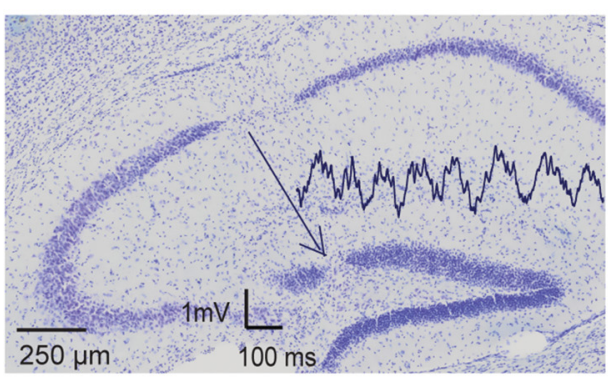

Figure 6. Oscillations in the dentate LFPare reduced during active behaviors $\operatorname{in} X$-irradiated mice (Sham: $n=4, X$-ray: $n=6)$.A,Average speed and ( $B$ ) place avoidance behaviormeasured across trials shows locomotion and place avoidance of the initial shock zone were indistinguishable between the groups, but X-irradiated mice avoided less than sham-irradiated mice on the conflict trials. C, Spectrograms from a pair of representative mice during unreinforced behaviors, pretraining and the stationary arena session 1 week after place avoidance training. $D$, Average power spectra comparing the sham-and X-irradiated groups. The spectra during training are averaged across the threetrials on that day. $\boldsymbol{E}$, Comparison of average power in the $\theta(6-10 \mathrm{~Hz})$ and $\gamma(30-100 \mathrm{~Hz})$ bands as a function of training. $\boldsymbol{F}$, A Nissl-stained section through dorsal hippocampus of a sham-irradiated mouse showing the recording electrode site. A 1 s LFP trace is shown, originating at the recording site.

unpublished observations). In the current study, we used $\mathrm{X}$-irradiation to ablate neurogenesis and waited 3 months before examining the effects. Although prior work found that inflammatory and stress responses to X-irradiation have abated by 3 months (Meshi et al., 2006), we nonetheless cannot exclude the possibility that such changes contribute to our observations, making it prudent to repeat the present studies with a different ablation technique. Indeed, neurogenesis is known to buffer the 
effects of stress (Snyder et al., 2011), and we were vigilant to look for behavioral signs, but found none. Indeed, the X- and shamirradiated mice are behaviorally indistinguishable during initial place avoidance training in the present study. They are also indistinguishable during more complex versions of the task with two simultaneous shock zones, as long as the task is the initial cognitive challenge given to the mice (Burghardt et al., 2012).

Ablating neurogenesis reduced responses to perforant path stimulation in naive mice (Lacefield et al., 2012) (Fig. 2A,B), which we also found in mice trained to avoid the initial shock location (Fig. 4D). This is consistent with enhanced dentate excitability in the presence of dentate neurogenesis, which tips the excitation-inhibition balance toward excitation due to numerous intrinsic (Freund and Buzsáki, 1996) and network mechanisms (Scharfman, 1995; Marín-Burgin et al., 2012). It may seem contradictory that $\mathrm{X}$-irradiation reduces dentate responses while left shifting E-S coupling, which indicates hyperexcitability in the transfer function that describes how synaptic activity generates spikes. Although synaptic responses are reduced by X-irradiation, there seem to be compensatory changes that involve enhancing the coupling between synaptic and spiking activity. In sham-irradiated mice, conflict learning caused similar increases in synapse-to-spike coupling, which was not observed in $\mathrm{X}$-irradiated mice. Importantly, these experience-dependent differences between the sham and X-irradiated groups emerged after conflict training but not after continued training to the initial shock location. This is reminiscent of experience modifying the integration of adult-born neurons into the dentate (Piatti et al., 2011). We emphasize that the physical environment is identical during place avoidance training to the initial and shifted shock zones, except during the $500 \mathrm{~ms}$ shock, which in aggregate was typically $<10 \mathrm{~s}$ of the $600 \mathrm{~s}$ session. Accordingly, the traininginduced changes in dentate electrophysiology probably reflect internal, cognitive variables rather than external differences, but experiments to directly test this hypothesis are beyond the present scope. Short-lasting changes in spatial exploration-induced increases and decreases in dentate recurrent inhibition were reported (Moser, 1996), but in light of the data presented in Figure 5 , they do not appear to contribute to the observed learninginduced changes in excitability.

The training-induced changes reflect long-term, experiencedependent alterations of dentate function, as predicted by the role of maturing granule cells in activity-driven modifications of dentate network structure and synaptic plasticity (Mongiat and Schinder, 2011; Piatti et al., 2011). When inhibition is intact, LTP is greater in the presence of adult-born neurons (Massa et al., 2011). It might be assumed that changes in synaptic function would be larger in sham- compared with X-irradiated mice. We however observed a more complex pattern of experiencedependent changes in dentate synaptic function. Despite equivalent initial learning in the two groups, synaptic responses were unchanged after initial training in the X-irradiated mice (Fig. $5 B$ ), whereas in sham-irradiated mice with intact neurogenesis, synaptic responses were strengthened (Fig. 5A). Furthermore, conflict training caused increased synaptic responses and enhanced E-S coupling in the X-irradiated mice, which were behaviorally impaired, whereas in the sham controls, conflict training caused decreased synaptic responses and adjusted E-S coupling in the direction of the naive state. Clearly, the mapping of neurogenesis-dependent LTP and learning-induced synaptic function in the dentate gyrus is complex, but worthy of further investigation. Additionally, dentate $\theta$ oscillations tended to be weaker in behaving $\mathrm{X}$-irradiated mice, and this trend contin- ued after training. Because $\theta$ oscillations organize perisomatic GABAergic inhibition (Buzsáki et al., 1981; Kuang et al., 2010; Royer et al., 2012), this is additional evidence of experiencedependent alterations in excitation-inhibition coupling after reduced neurogenesis. In summary, ablating adult neurogenesis reduces dentate responses yet causes hyperexcitable output in the coupling of the synaptic and spike responses to neocortical stimulation. Furthermore, ablation of neurogenesis reduces $\theta$ oscillations and prevents adjustments in dentate synaptic-spike coupling that accompany conflict learning in mice with normal neurogenesis.

\section{Pattern separation and memory discrimination}

Adult-born granule cells have a role in tasks that involve distinguishing between current experiences and similar but distinct experiences, what has been called cognitive discriminations (Jessberger et al., 2009; Sahay et al., 2011b; Nakashiba et al., 2012; Deng et al., 2013). These have been called "behavioral pattern separation" tasks (Gilbert et al., 1998, 2001; Sahay et al., 2011b), which should not be confused with "pattern separation," the neural computation that produces neural output representations that are more distinct than the corresponding input representations (Marr, 1971; McClelland et al., 1995; Santoro, 2013). Place cell recordings suggest that dentate gyrus performs pattern separation (Leutgeb et al., 2007; Neunuebel and Knierim, 2014). It is natural to equate the properties of maturing granule cells with their role in pattern separation and the ability to discriminate memories of similar experiences. We call this ability "memory discrimination" or "cognitive discrimination" to distinguish the neural computation from a psychological consequence (Aimone et al., 2011; Sahay et al., 2011a; Winocur et al., 2012). If dentate responses to neocortical stimulation estimate the neural, synaptic infrastructure for representing experience, then the present findings are direct evidence that the dentate gyrus changes its representational infrastructure after cognitive discrimination learning. This estimate of pattern separation is attenuated when learning occurs without adult neurogenesis, suggesting that pattern separation and cognitive discrimination are realized by neurogenesis-dependent adaptive changes to dentate network excitability. This view is consistent with substantial evidence that loss of neurogenesis spares learning of reliable relationships between stimuli and events. However, it does result in loss of cognitive discrimination ability, which is observed as behavioral inflexibility when learning is required in response to changes in environment and/or task demands, as described for place avoidance (Fig. 4) (Burghardt et al., 2012) and tasks using the water maze and conditioned fear paradigms (Dupret et al., 2008; Winocur et al., 2012; Garthe et al., 2014; Swan et al., 2014).

\section{Distinguishing between memory storage and memory use}

The Introduction reviewed two classes of hypotheses for the role of maturing granule cells in memory. Direct hypotheses posit adult-born granule cells directly store and represent information in their discharge (Fig. 1B). Indirect hypotheses posit these cells organize network activity by coordinating excitation and inhibition (Fig. $1 C$ ). We found that $\mathrm{X}$-irradiation increases spiking responses relative to the synaptic response, as predicted by indirect hypotheses. This is consistent with maturing granule cells making monosynaptic contacts with dentate interneurons (Toni et al., 2008), thereby contributing to the balance between excitation, inhibition, and plasticity (Singer et al., 2011). Direct hypotheses predict impaired memory encoding, but this was not observed, perhaps because the place avoidance task does not ex- 
ceed the residual memory capacity after X-irradiation. This is however unlikely because X-irradiated mice are also unimpaired in learning to avoid a second shock zone in a novel environment or two shock zones during initial training (Burghardt et al., 2012). Perhaps encoding deficits are more likely to be found in tasks that strain the operational limits of the dentate network (Denny et al., 2014), which appears not to be the case in the present studies. The conflict learning impairment that failed to change dentate function in the absence of neurogenesis (Fig. 4) is associated with excessive Arc protein expression in granule cells (Burghardt et al., 2012). These findings are consistent with indirect hypotheses that posit a key role for maturing granule cells in increasing inhibition. Figure $1 C$ depicts the dentate as a competitive network in which mature granule cells preferentially excite inhibitory neurons and the inhibition increases as granule cells mature (Temprana et al., 2015), although a more complex relationship to inhibition is emerging (Bergami et al., 2015). Normal function is maintained after X-irradiation when the competition between representational patterns of neural activity is low. However, X-irradiation impairs appropriate selection of neural representational responses when competition is high, as in cognitive discrimination trials. The present findings provide evidence that maturing granule cells contribute specifically to the cognitiondriven modification of neural network activity, emphasizing the role of neurogenesis in the processing of information in memory rather than storage itself.

\section{References}

Aimone JB, Wiles J, Gage FH (2009) Computational influence of adult neurogenesis on memory encoding. Neuron 61:187-202. CrossRef Medline

Aimone JB, Deng W, Gage FH (2010) Put them out to pasture? What are old granule cells good for, anyway? Hippocampus 20:1124-1125. CrossRef Medline

Aimone JB, Deng W, Gage FH (2011) Resolving new memories: a critical look at the dentate gyrus, adult neurogenesis, and pattern separation. Neuron 70:589-596. CrossRef Medline

Alvarez-Buylla A, Lim DA (2004) For the long run: maintaining germinal niches in the adult brain. Neuron 41:683-686. CrossRef Medline

Bergami M, Masserdotti G, Temprana SG, Motori E, Eriksson TM, Göbel J, Yang SM, Conzelmann KK, Schinder AF, Göotz M, Berninger B (2015a) A critical period for experience-dependent remodeling of adult-born neuron connectivity. Neuron 85:710-717. CrossRef Medline

Burghardt NS, Park EH, Hen R, Fenton AA (2012) Adult-born hippocampal neurons promote cognitive flexibility in mice. Hippocampus 22: 1795-1808. CrossRef Medline

Buzsáki G (2010) Neural syntax: cell assemblies, synapsembles, and readers. Neuron 68:362-385. CrossRef Medline

Buzsáki G, Grastyàn E, Czopf J, Kellènyi L, Prohaska O (1981) Changes in neuronal transmission in the rat hippocampus during behavior. Brain Res 225:235-247. CrossRef Medline

Deng W, Mayford M, Gage FH (2013) Selection of distinct populations of dentate granule cells in response to inputs as a mechanism for pattern separation in mice. Elife 2:e00312. CrossRef Medline

Denny CA, Kheirbek MA, Alba EL, Tanaka KF, Brachman RA, Laughman KB, Tomm NK, Turi GF, Losonczy A, Hen R (2014) Hippocampal memory traces are differentially modulated by experience, time, and adult neurogenesis. Neuron 83:189-201. CrossRef Medline

Dupret D, Revest JM, Koehl M, Ichas F, De Giorgi F, Costet P, Abrous DN, Piazza PV (2008) Spatial relational memory requires hippocampal adult neurogenesis. PLoS One 3:e1959. CrossRef Medline

Freund TF, Buzsáki G (1996) Interneurons of the hippocampus. Hippocampus 6:347-470. Medline

Garthe A, Huang Z, Kaczmarek L, Filipkowski RK, Kempermann G (2014) Not all water mazes are created equal: cyclin D2 knock-out mice with constitutively suppressed adult hippocampal neurogenesis do show specific spatial learning deficits. Genes Brain Behav 13:357-364. CrossRef Medline

Ge S, Pradhan DA, Ming GL, Song H (2007) GABA sets the tempo for activitydependent adult neurogenesis. Trends Neurosci 30:1-8. CrossRef Medline
Gilbert PE, Kesner RP, DeCoteau WE (1998) Memory for spatial location: role of the hippocampus in mediating spatial pattern separation. J Neurosci 18:804-810. Medline

Gilbert PE, Kesner RP, Lee I (2001) Dissociating hippocampal subregions: double dissociation between dentate gyrus and CA1. Hippocampus 11: 626-636. CrossRef Medline

Ikrar T, Guo N, He K, Besnard A, Levinson S, Hill A, Lee HK, Hen R, Xu X, Sahay A (2013) Adult neurogenesis modifies excitability of the dentate gyrus. Front Neural Circuits 7:204. CrossRef Medline

Jessberger S, Clark RE, Broadbent NJ, Clemenson GD Jr, Consiglio A, Lie DC, Squire LR, Gage FH (2009) Dentate gyrus-specific knockdown of adult neurogenesis impairs spatial and object recognition memory in adult rats. Learn Mem 16:147-154. CrossRef Medline

Kempermann G (2008) The neurogenic reserve hypothesis: what is adult hippocampal neurogenesis good for? Trends Neurosci 31:163-169. CrossRef Medline

Kuang H, Lin L, Tsien JZ (2010) Temporal dynamics of distinct CA1 cell populations during unconscious state induced by ketamine. PLoS One 5:e15209. CrossRef Medline

Lacefield CO, Itskov V, Reardon T, Hen R, Gordon JA (2012) Effects of adult-generated granule cells on coordinated network activity in the dentate gyrus. Hippocampus 22:106-116. CrossRef Medline

Lasztóczi B, Klausberger T (2014) Layer-specific GABAergic control of distinct gamma oscillations in the CA1 hippocampus. Neuron 81:11261139. CrossRef Medline

Leutgeb JK, Leutgeb S, Moser MB, Moser EI (2007) Pattern separation in the dentate gyrus and CA3 of the hippocampus. Science 315:961-966. CrossRef Medline

Luu P, Sill OC, Gao L, Becker S, Wojtowicz JM, Smith DM (2012) The role of adult hippocampal neurogenesis in reducing interference. Behav Neurosci 126:381-391. CrossRef Medline

Madroñal N, Gruart A, Sacktor TC, Delgado-García JM (2010) PKMzeta inhibition reverses learning-induced increases in hippocampal synaptic strength and memory during trace eyeblink conditioning. PLoS One 5:e10400. CrossRef Medline

Marín-Burgin A, Mongiat LA, Pardi MB, Schinder AF (2012) Unique processing during a period of high excitation/inhibition balance in adultborn neurons. Science 335:1238-1242. CrossRef Medline

Marr D (1971) Simple memory: a theory for archicortex. Philos Trans R Soc Lond B Biol Sci 262:23-81. CrossRef Medline

Massa F, Koehl M, Wiesner T, Grosjean N, Revest JM, Piazza PV, Abrous DN, Oliet SH (2011) Conditional reduction of adult neurogenesis impairs bidirectional hippocampal synaptic plasticity. Proc Natl Acad Sci U S A 108:6644-6649. CrossRef Medline

McClelland JL, McNaughton BL, O'Reilly RC (1995) Why there are complementary learning systems in the hippocampus and neocortex: insights from the successes and failures of connectionist models of learning and memory. Psychol Rev 102:419-457. CrossRef Medline

Meshi D, Drew MR, Saxe M, Ansorge MS, David D, Santarelli L, Malapani C, Moore H, Hen R (2006) Hippocampal neurogenesis is not required for behavioral effects of environmental enrichment. Nat Neurosci 9:729_ 731. CrossRef Medline

Ming GL, Song H (2011) Adult neurogenesis in the mammalian brain: significant answers and significant questions. Neuron 70:687-702. CrossRef Medline

Mongiat LA, Schinder AF (2011) Adult neurogenesis and the plasticity of the dentate gyrus network. Eur J Neurosci 33:1055-1061. CrossRef Medline

Mongiat LA, Espósito MS, Lombardi G, Schinder AF (2009) Reliable activation of immature neurons in the adult hippocampus. PLoS One 4:e5320. CrossRef Medline

Moser EI (1996) Altered inhibition of dentate granule cells during spatial learning in an exploration task. J Neurosci 16:1247-1259. Medline

Moser E, Moser MB, Andersen P (1993) Synaptic potentiation in the rat dentate gyrus during exploratory learning. Neuroreport 5:317-320. CrossRef Medline

Moser EI, Moser MB, Andersen P (1994) Potentiation of dentate synapses initiated by exploratory learning in rats: dissociation from brain temperature, motor activity, and arousal. Learn Mem 1:55-73. CrossRef Medline

Nakashiba T, Cushman JD, Pelkey KA, Renaudineau S, Buhl DL, McHugh TJ, Rodriguez Barrera V, Chittajallu R, Iwamoto KS, McBain CJ, Fanselow MS, Tonegawa S (2012) Young dentate granule cells mediate pattern 
separation, whereas old granule cells facilitate pattern completion. Cell 149:188-201. CrossRef Medline

Neunuebel JP, Knierim JJ (2014) CA3 retrieves coherent representations from degraded input: direct evidence for CA3 pattern completion and dentate gyrus pattern separation. Neuron 81:416-427. CrossRef Medline

Olypher AV, Klement D, Fenton AA (2006) Cognitive disorganization in hippocampus: a physiological model of the disorganization in psychosis. J Neurosci 26:158-168. CrossRef Medline

Piatti VC, Davies-Sala MG, Espósito MS, Mongiat LA, Trinchero MF, Schinder AF (2011) The timing for neuronal maturation in the adult hippocampus is modulated by local network activity. J Neurosci 31 : 7715-7728. CrossRef Medline

Piatti VC, Ewell LA, Leutgeb JK (2013) Neurogenesis in the dentate gyrus: carrying the message or dictating the tone. Front Neurosci 7:50. CrossRef Medline

Rangel LM, Quinn LK, Chiba AA, Gage FH, Aimone JB (2013) A hypothesis for temporal coding of young and mature granule cells. Front Neurosci 7:75. CrossRef Medline

Rolls ET, Stringer SM, Trappenberg TP (2002) A unified model of spatial and episodic memory. Proc Biol Sci 269:1087-1093. CrossRef Medline

Royer S, Zemelman BV, Losonczy A, Kim J, Chance F, Magee JC, Buzsáki G (2012) Control of timing, rate and bursts of hippocampal place cells by dendritic and somatic inhibition. Nat Neurosci 15:769-775. CrossRef Medline

Sahay A, Scobie KN, Hill AS, O'Carroll CM, Kheirbek MA, Burghardt NS, Fenton AA, Dranovsky A, Hen R (2011a) Increasing adult hippocampal neurogenesis is sufficient to improve pattern separation. Nature 472:466470. CrossRef Medline

Sahay A, Wilson DA, Hen R (2011b) Pattern separation: a common function for new neurons in hippocampus and olfactory bulb. Neuron 70 : 582-588. CrossRef Medline

Santarelli L, Saxe M, Gross C, Surget A, Battaglia F, Dulawa S, Weisstaub N, Lee J, Duman R, Arancio O, Belzung C, Hen R (2003) Requirement of hippocampal neurogenesis for the behavioral effects of antidepressants. Science 301:805-809. CrossRef Medline

Santoro A (2013) Reassessing pattern separation in the dentate gyrus. Front Behav Neurosci 7:96. CrossRef Medline

Scharfman HE (1995) Electrophysiological evidence that dentate hilar mossy cells are excitatory and innervate both granule cells and interneurons. J Neurophysiol 74:179-194. Medline

Schmidt-Hieber C, Jonas P, Bischofberger J (2004) Enhanced synaptic plasticity in newly generated granule cells of the adult hippocampus. Nature 429:184-187. CrossRef Medline

Schroeder CE, Lakatos P (2009) The gamma oscillation: master or slave? Brain Topogr 22:24-26. CrossRef Medline

Singer BH, Gamelli AE, Fuller CL, Temme SJ, Parent JM, Murphy GG (2011) Compensatory network changes in the dentate gyrus restore long-term potentiation following ablation of neurogenesis in young-adult mice. Proc Natl Acad Sci U S A 108:5437-5442. CrossRef Medline

Snyder JS, Soumier A, Brewer M, Pickel J, Cameron HA (2011) Adult hippocampal neurogenesis buffers stress responses and depressive behaviour. Nature 476:458-461. CrossRef Medline

Somogyi P, Katona L, Klausberger T, Lasztóczi B, Viney TJ (2014) Temporal redistribution of inhibition over neuronal subcellular domains underlies state-dependent rhythmic change of excitability in the hippocampus. Philos Trans R Soc Lond B Biol Sci 369:20120518. CrossRef Medline

Swan AA, Clutton JE, Chary PK, Cook SG, Liu GG, Drew MR (2014) Characterization of the role of adult neurogenesis in touch-screen discrimination learning. Hippocampus 24:1581-1591. CrossRef Medline

Temprana SG, Mongiat LA, Yang SM, Trinchero MF, Alvarez DD, Kropff E, Giacomini D, Beltramone N, Lanuza GM, Schinder AF (2015) Delayed coupling to feedback inhibition during a critical period for the integration of adult-born granule cells. Neuron 85:116-130. CrossRef Medline

Toni N, Laplagne DA, Zhao C, Lombardi G, Ribak CE, Gage FH, Schinder AF (2008) Neurons born in the adult dentate gyrus form functional synapses with target cells. Nat Neurosci 11:901-907. CrossRef Medline

Tronel S, Belnoue L, Grosjean N, Revest JM, Piazza PV, Koehl M, Abrous DN (2012) Adult-born neurons are necessary for extended contextual discrimination. Hippocampus 22:292-298. CrossRef Medline

Whitlock JR, Heynen AJ, Shuler MG, Bear MF (2006) Learning induces long-term potentiation in the hippocampus. Science 313:1093-1097. CrossRef Medline

Winocur G, Becker S, Luu P, Rosenzweig S, Wojtowicz JM (2012) Adult hippocampal neurogenesis and memory interference. Behav Brain Res 227:464-469. CrossRef Medline 